\title{
Genetic diversity and relatedness within and between species of the genus Oligoryzomys (Rodentia; Sigmodontinae)
}

\author{
Trott, A. ${ }^{\mathrm{a}}$, Callegari-Jacques, SM. ${ }^{\mathrm{a}, \mathrm{b}}$, Oliveira, LFB. ${ }^{\mathrm{c}}$, Langguth, $A .{ }^{\mathrm{d}}$ and Mattevi, MS. ${ }^{\mathrm{a}, \mathrm{*}}$ \\ aDepartamento de Genética, Universidade Federal do Rio Grande do Sul, Porto Alegre, RS, Brazil

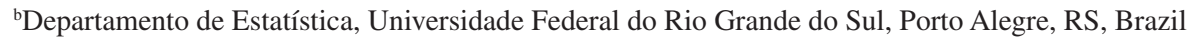 \\ 'Museu Nacional, Setor de Mastozoologia, Universidade Federal do Rio de Janeiro, RJ, Brazil \\ ${ }^{d}$ Departamento de Sistemática e Ecologia, Universidade Federal da Paraíba, João Pessoa, PB, Brazil \\ ePPGenética e Toxicologia Aplicada, Universidade Luterana do Brasil - ULBRA, \\ Av. Farroupilha, 8001, CEP 92450-900, Canoas, RS, Brazil \\ *e-mail: mattevi@terra.com.br
}

Received May 12, 2005 - Accepted August 29, 2005 - Distributed February 28, 2007

(With 3 figures)

\begin{abstract}
A RAPD analysis on six species of the rodent genus Oligoryzomys trapped in a wide area (ranging from $01^{\circ} \mathrm{N}$ to $32^{\circ} \mathrm{S}$ ) of Brazilian territory was performed in order to determine the levels of genetic variability within and between its populations and species. One-hundred and ninety-three animals were collected in 13 different sites (corresponding to 17 samples) located at Pampas, Atlantic Rain Forest, Cerrado, and Amazon domains. Oligoryzomys sp., O. nigripes (8 populations), O. flavescens (4 populations), O. moojeni, O. stramineus, and $O$. fornesi were the taxa analyzed. Of the 20 primers tested, 4 generated a total of 75 polymorphic products simultaneously amplified in 151 specimens. Various diversity estimators analyzed showed considerable differences between species and populations, indicating a great genetic variation occurring in the Oligoryzomys taxa investigated. A cluster analysis was made using Nei's standard genetic distances, however, it did not correlate the genetic heterogeneity of the species and populations with the geographical areas.
\end{abstract}

Keywords: RAPD, DNA polymorphisms, Oligoryzomys, genetic distances, population genetics.

\section{Diversidade e relações genéticas dentro e entre espécies do gênero Oligoryzomys (Rodentia; Sigmodontinae)}

\begin{abstract}
Resumo
Foram realizadas análises com RAPD em seis espécies de roedores do gênero Oligoryzomys capturados em uma ampla área (estendendo-se de $01^{\circ} \mathrm{N}$ a $32^{\circ} \mathrm{S}$ ) do território brasileiro com o objetivo de determinar os níveis de variabilidade genética dentro e entre as populações e espécies. Cento e noventa e três animais foram coletados em 13 locais diferentes (correspondendo a 17 amostras) localizados nos Pampas, Floresta Atlântica, Cerrado e Amazônia. Oligoryzomys sp., $O$. nigripes (8 populações), $O$. flavescens (4 populações), $O$. moojeni, $O$. stramineus e $O$. fornesi foram as espécies analisadas. Vinte primers foram testados, sendo que quatro deles geraram um total de 75 produtos polimórficos amplificados simultaneamente em 151 exemplares. Várias estimativas de diversidade apresentaram diferenças consideráveis entre as espécies e as populações, indicando uma grande variação genética entre os taxa de Oligoryzomys investigados. As análises de agrupamento utilizando a distância genética de Nei, entretanto, não correlacionaram a heterogeneidade genética das espécies e populações com as áreas geográficas.
\end{abstract}

Palavras-chave: RAPD, polimorfismos de DNA, Oligoryzomys, distâncias genéticas, genética de populações.

\section{Introduction}

Rodents are important members of the mammalian fauna in South America, comprising approximately $45 \%$ of the species (Reig, 1986). On this continent, all the species of muroid rodents are cricetids ranked under the subfamily Sigmodontinae. The subfamily encloses more than 400 species under more than 76 genera (Musser and Carleton, 2005) that are allocated in 8 tribes (Reig, 1984; Smith and Patton, 1999). Among these tribes, the oryzomyine group constitutes the largest tribal-level assemblage derived from the radiation that invaded South 
America through Central America, via the northern Andes in probably the Early Pliocene (Reig, 1984, 1986; Carleton and Musser, 1989). Taking into account dental, cranial, phallic and chromosomal characters, their members are considered as the most primitive South American sigmodontines (Hooper and Musser, 1964; Hershkovitz, 1966, 1972; Gardner and Patton, 1976; Reig, 1980, 1981, 1986; Voss and Linzey, 1981; Carleton and Musser 1989, among others), a notion which has been falsified by molecular phylogenetic analyses to date (e.g. Engel et al., 1998; Smith and Patton, 1999; D’Elia, 2003; Weksler, 2003).

The tribe consists of 15 genera among them Oligoryzomys, a genus which was first proposed as a subgenus of genus Oryzomys by Bangs (1900) in an attempt to rank together a group of species whose members were distinguished by morphologic measurements. These marker characters include, among others, small body size, the tail longer than the head and body, short and broad hind feet, a small skull but with a stout appearance, and rostrum relatively broad and stocky. They are terrestrial, nocturnal rats that feed on seeds, fruits, and insects, and some of their species can be agricultural pests or significant reservoirs of hantavirus (Emmons and Feer, 1990; Powers et al., 1999). This genus is widely distributed, occupying Central and South America, from southern Mexico to southern Chile.

In the past, the status of Oligoryzomys as a genus was controversial. Currently, it is considered as a full genus of Sigmodontinae (Carleton and Musser, 1989), with 21 recognized species (the ones recognized by Musser and Carleton (2005) plus the ones described afterwards). Although it is a speciose genus, very little research has been done about the amount and/or the limits of genetic variation or about the relationship between its species. The studies carried out were mainly karyological but a recent revision (Andrades-Miranda et al., 2001 ) showed that the diploid numbers of Oligoryzomys $(2 \mathrm{n}=44-70)$ fall inside the range of those observed in Oryzomys $(2 \mathrm{n}=34-80)$ and this characteristic was therefore a non-distinctive feature. No consistent results were found in the few other studies of a small number of Oligoryzomys species that attempted to show a genetic structuring of their populations or to explain their relationship with other oryzomyine genera (Dickerman and Yates, 1995; Myers et al., 1995; Patton et al., 1996; Chiappero et al., 1997; Perini et al., 2004).

In this work, we are reporting the results of a RAPD analysis performed on six species of Oligoryzomys genus, collected in 13 localities of the Amazonian, Cerrado, Atlantic Rain Forest, and Pampas Brazilian domains. The main objectives were to evaluate the genetic diversity and relatedness within and between Oligoryzomys populations.

\section{Materials and Methods}

A total number of 193 animals of 6 species of the genus Oligoryzomys was collected in 13 different sites (corresponding to 17 samples, Table 1 and Figure 1), located at Pampas (Taim, Mostardas, Charqueadas, Tramandaí, Osório, Torres, Sapiranga, and Tainhas), the Atlantic Forest (Monte Verde), Cerrado (Corumbá, Serra da Mesa, and Fazenda Regalito), and Amazon (Tartarugalzinho) Brazilian domains. Tissue and cytological preparations (up to the stage of obtaining the cell

Table 1. Species, acronyms, karyotypic data (2n/NA), number of specimens analyzed (N), and geographical location of each locality studied.

\begin{tabular}{|c|c|c|c|c|}
\hline Species (acronyms) & 2n/NA & $\mathbf{N}$ & & Sites \\
\hline \multirow[t]{8}{*}{ O. nigripes $(\mathrm{ONI})$} & $62 / 80-82$ & 20 & CHA & - Charqueadas $\left(29^{\circ} 57^{\prime} \mathrm{S}\right.$ and $\left.51^{\circ} 37^{\prime} \mathrm{W}\right)$ \\
\hline & & 10 & TAH & - Tainhas $\left(29^{\circ} 16^{\prime} \mathrm{S}\right.$ and $\left.50^{\circ} 18^{\prime} \mathrm{W}\right)$ \\
\hline & & 20 & SAP & - Sapiranga $\left(29^{\circ} 38^{\prime} \mathrm{S}\right.$ and $\left.51^{\circ} 00^{\prime} \mathrm{W}\right)$ \\
\hline & & 21 & OSO & - Osório $\left(30^{\circ} 53^{\prime} \mathrm{S}\right.$ and $\left.50^{\circ} 16^{\prime} \mathrm{W}\right)$ \\
\hline & & 20 & MOS & - Mostardas $\left(31^{\circ} 10^{\prime} \mathrm{S}\right.$ and $\left.51^{\circ} 31^{\circ} \mathrm{W}\right)$ \\
\hline & & 15 & TOR & - Torres $\left(29^{\circ} 19^{\prime} \mathrm{S}\right.$ and $\left.49^{\circ} 46^{\prime} \mathrm{W}\right)$ \\
\hline & & 5 & MVE & - Monte Verde (19053’ S and 41057’ W) \\
\hline & & 12 & $\mathrm{COR}$ & - Corumbá $\left(17^{\circ} 44^{\prime} \mathrm{S}\right.$ and $\left.48^{\circ} 37^{\prime} \mathrm{W}\right)$ \\
\hline \multirow[t]{4}{*}{ O. flavescens (OFL) } & $64-66 / 64-67 *$ & 15 & CHA & - Charqueadas \\
\hline & & 10 & TAH & - Tainhas \\
\hline & & 10 & TRA & - Tramandaí (29 $54^{\circ} \mathrm{S}$ and $\left.50^{\circ} 16^{\prime} \mathrm{W}\right)$ \\
\hline & & 10 & TAI & - Taim $\left(32^{\circ} 29^{\prime} \mathrm{S}\right.$ and $\left.52^{\circ} 34^{\prime} \mathrm{W}\right)$ \\
\hline O. moojeni (OMO) & $70 / 74$ & 10 & SME & - Serra da Mesa $\left(13^{\circ} 45^{\prime} \mathrm{S}\right.$ and $\left.47^{\circ} 50^{\prime} \mathrm{W}\right)$ \\
\hline Oligoryzomys sp. (OSP) & $66 / 74$ & 6 & TAR & - Tartarugalzinho $\left(01^{\circ} 17^{\prime} \mathrm{N}\right.$ and $\left.50^{\circ} 48^{\prime} \mathrm{W}\right)$ \\
\hline O. stramineus $(\mathrm{OST})$ & $52 / 68$ & 3 & REG & - Fazenda Regalito $\left(14^{\circ} 29^{\prime} \mathrm{S}\right.$ and $\left.46^{\circ} 06^{\prime} \mathrm{W}\right)$ \\
\hline O. fornesi $(\mathrm{OFO})$ & $62 / 64$ & 6 & CSM & - Corumbá and Serra da Mesa \\
\hline
\end{tabular}

*Range of the autosomal arms observed in the specimens included in this analysis. 


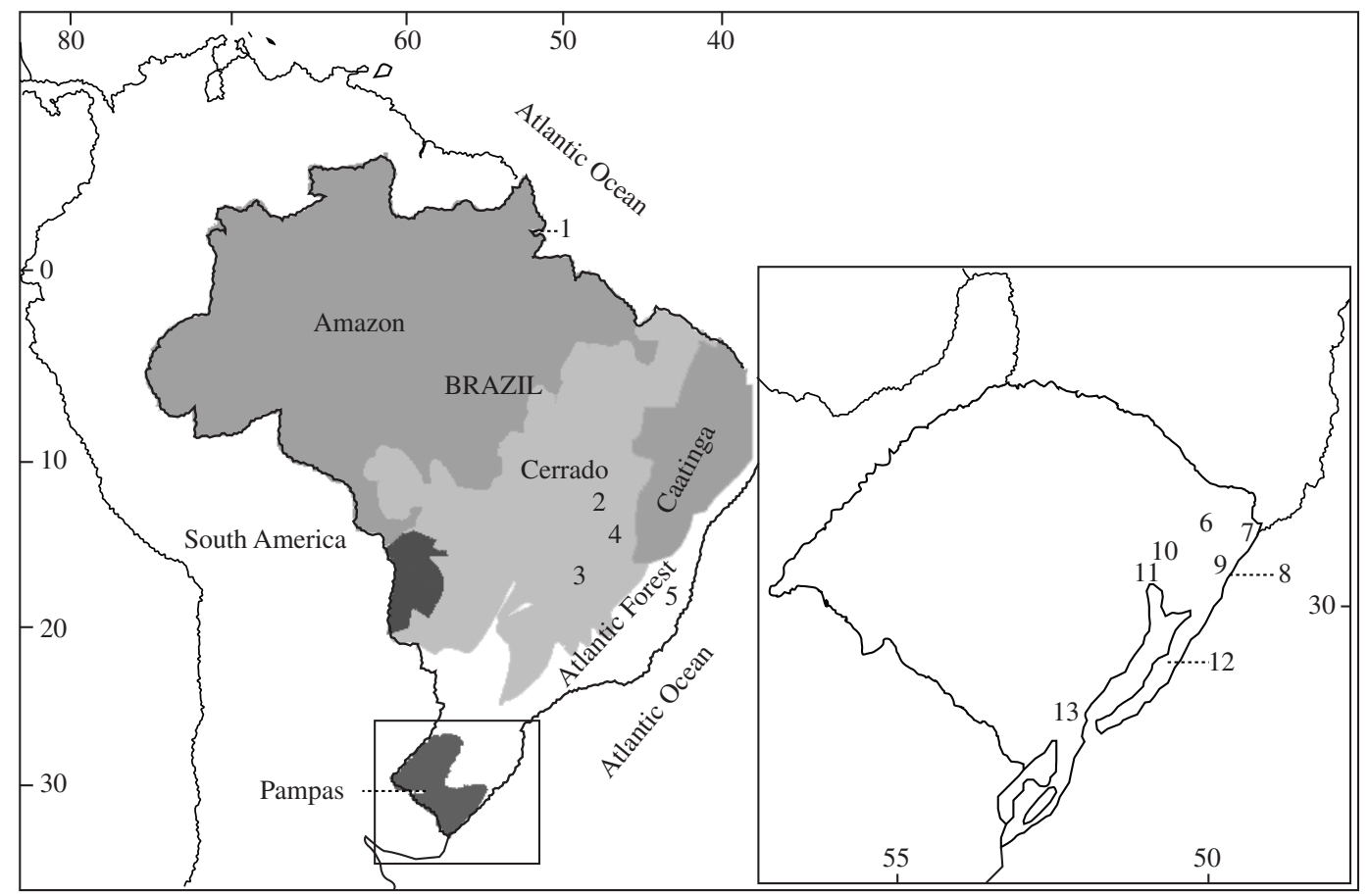

Figure 1. Localities of collect: 1) Tartarugalzinho (AP); 2) Serra da Mesa(GO); 3) Corumbá (GO); 4) Fazenda Regalito (GO); 5) Monte Verde (ES); 6) Tainhas (RS); 7) Torres (RS); 8) Tramandaí (RS); 9) Osório (RS); 10) Sapiranga (RS); 11) Charqueadas (RS); 12) Mostardas (RS); and 13) Taim (RS).

suspensions) were performed in the field. All animals analyzed were karyotyped (karyotypes are available in Andrades-Miranda et al., 2001) and the skins and skulls of these specimens are stored in the Mammals Collection of the Museu Nacional, Rio de Janeiro.

DNA was extracted from the kidney, liver, heart or muscle using the standard protocol of Medrano et al. (1990). Twenty primers of the OPA kit of Operon Technologies (Alameda, CA, USA, OPA1 to OPA20) were tested according to the method of Williams et al. (1990) with some modifications: $100 \mathrm{ng}$ of genomic DNA were mixed to $2.5 \mathrm{U}$ of Taq polymerase, $100 \mu \mathrm{M}$ of dNTPs and $0.2 \mu \mathrm{M}$ of primer in a total volume of $25 \mu \mathrm{L}$. PCR protocol: After an initial denaturation at $94{ }^{\circ} \mathrm{C}$ for 3 minutes, 45 cycles were repeated $\left(94{ }^{\circ} \mathrm{C}\right.$ for $30 \mathrm{sec}-$ onds, $36{ }^{\circ} \mathrm{C}$ for 30 seconds and $72{ }^{\circ} \mathrm{C}$ for 30 seconds) with a final extension of 7 minutes at $72{ }^{\circ} \mathrm{C}$.

The amplification products were analyzed by electrophoresis in agarose gel 1.4\% in TAE 50 times, detected by staining with ethidium bromide and viewed under UV light. DNA of Mus musculus was used as a positive control. As a negative control only the reagents were amplified, without the DNA sample. The technique reproducibility was tested by comparing the bands generated by 4 primers in some random choice samples with those bands obtained in a second round of amplification conducted by another investigator. In all the cases the patterns observed in the second amplification were equal to those seen in the first.
RAPD markers were assumed to be selectively neutral and were inherited as dominant Mendelian character in the Hardy-Weinberg equilibrium. The allele frequencies were estimated according to Lynch and Millingan (1994). The amount of genetic variation within the species and populations was measured by the proportion of loci in which the frequency of the most common allele did not exceed 0.99 (polymorphic loci - 99\% criterion) and the unbiased average heterozygosity (Nei and Roychoudhury, 1974), using the program TFPGA (Miller, 1997). The genetic structure of the populations was evaluated by means of an analysis of molecular variance (AMOVA; Weir and Cockerham, 1984; Excoffier et al., 1992; Weir, 1996). F-statistics analogs were estimated for interspecies and intraspecies relationships and their significance tested using the programs TFPGA (Miller, 1997) and ARLEQUIN v.2001 (Schneider et al., 2001).

Nei's (1978) unbiased as well as Reynolds et al. (1983) genetic distances were calculated between species and populations. This information was used to derive unweighed pair-group (UPGMA) dendrograms, with bootstrap numbers obtained from 1000 permutations of the original data. These procedures were done with the program TFPGA (Miller, 1997).

Great-circle distances between the geographic locations of the studied populations of $O$. flavescens and $O$. nigripes were calculated from their latitudinal and 
longitudinal coordinates by means of a facility provided at the URL site (http://www.geocities.com/TheTropics/ Shores/3098/distance.html). The assessment and test of the association between the genetic and the geographical data was done by the Mantel procedure (Mantel, 1967; Smouse and Long, 1992) separately for each of these two species, using a routine of the program ARLEQUIN v.2001 (Schneider et al., 2001).

\section{Results}

\subsection{Species diversity and differentiation}

One-hundred and fifty-one specimens showed polymorphic bands (42 out of 193 individuals analyzed presented monomorphic bands only). Of the 20 primers tested, 4 generated a total of 75 polymorphic products (Table 2).

The number of amplified fragments (total and scored per primer and species), the average number of bands, the percentage of polymorphic bands, and the average heterozygosities obtained in the 6 species of genus Oligoryzomys are shown in Table 2 . The various estimators of the genetic diversity analyzed showed differences between species. The number of phenotypes scored varied from a minimum of 15 in Oligoryzomys sp. up to a value of approximately five times higher in $O$. nigripes and the average number of bands of $O$. moojeni (18.8) was twice the number (9.2) seen in Oligoryzomys sp. The percentage of polymorphic bands and the average heterozygosities were, respectively, as low as $14.5 \%$ and 0.06 in Oligoryzomys sp. and as high as $90.8 \%$ and 0.17 in $O$. nigripes. The genetic divergence among the 6 species of the genus Oligoryzomys studied was $\phi_{\mathrm{ST}}=0.35 \pm 0.05$, statistically significant at the 0.001 level (for this analysis 1 population was used, at random, per species).

Allele frequencies obtained in the 6 species investigated were used to calculate Nei's standard genetic distances (Table 3). O. fornesi and O. stramineus were the most similar species, whereas the latter and $O$. moojeni were the most genetically distant. These and other RAPD (dis)similarities between species can be

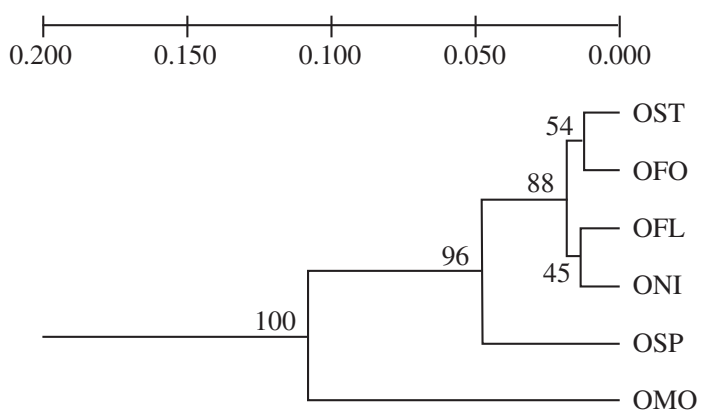

Figure 2. UPGMA dendrogram showing the genetic relationships among six species of genus Oligoryzomys, based on 75 RAPD markers. Numbers in the dendrogram represent bootstrap numbers obtained in 1,000 replications. OST: $O$. stramineus: OFO: O. fornesi; OFL: O. flavescens; ONI: O. nigripes; OMO: O. moojeni; OSP: Oligoryzomys sp.

Table 2. Genetic variability in RAPD markers studied in six species of the genus Oligoryzomys: number of scored phenotypes, mean number of bands, percentage of polymorphic loci $\left(99 \%\right.$ criterion) and unbiased average heterozygosity $\left(\mathrm{H}_{\mathrm{unb}}\right)$.

\begin{tabular}{lccccccc}
\hline \multicolumn{1}{c}{ Primer } & \multicolumn{7}{c}{ Number of amplified fragments } \\
\cline { 2 - 8 } & $\begin{array}{c}\text { All samples } \\
(\mathbf{n = 1 5 1})\end{array}$ & $\begin{array}{c}\text { ONI } \\
(\mathbf{n = 9 6})\end{array}$ & $\begin{array}{c}\text { OFL } \\
(\mathbf{n}=\mathbf{3 4})\end{array}$ & $\begin{array}{c}\text { OMO } \\
(\mathbf{n = 1 0})\end{array}$ & $\begin{array}{c}\text { OSP } \\
(\mathbf{n = 4})\end{array}$ & $\begin{array}{c}\text { OST } \\
(\mathbf{n = 3})\end{array}$ & $\begin{array}{c}\text { OFO } \\
(\mathbf{n}=\mathbf{4})\end{array}$ \\
\hline OPA 7 (5'GAAACGGGTG3') & 18 & 16 & 15 & 9 & 4 & 3 & 5 \\
OPA 8 (5'GTGACGTAGG3') & 18 & 18 & 16 & 10 & 6 & 9 & 12 \\
OPA 10 (5'GTGATCGCAC3') & 21 & 19 & 19 & 8 & 1 & 6 & 8 \\
OPA 11 (5'CAATCGCCGT3') & 18 & 18 & 15 & 11 & 4 & 7 & 8 \\
Scored phenotypes & 75 & 71 & 65 & 38 & 15 & 25 & 33 \\
Mean number of bands & 13.7 & 14.0 & 12.2 & 18.8 & 9.2 & 12.7 & 12.2 \\
\pm SE (mean) & \pm 0.31 & \pm 0.35 & \pm 0.65 & \pm 0.68 & \pm .048 & \pm 0.33 & \pm 1.70 \\
Polymorphic loci (\%) & 88.2 & 90.8 & 84.2 & 39.5 & 14.5 & 36.8 & 42.1 \\
$\mathrm{H}_{\text {unb }}$ & 0.166 & 0.167 & 0.141 & 0.112 & 0.058 & 0.143 & 0.135 \\
\hline
\end{tabular}

Table 3. Nei's (1978) unbiased standard genetic distances between six species of Oligoryzomys.

\begin{tabular}{lccccc}
\hline \multicolumn{1}{c}{ Species } & O. flavescens & O. nigripes & Oligoryzomys sp. & O. stramineus & O. fornesi \\
\hline O. nigripes & 0.0156 & - & - & - & - \\
Oligoryzomys sp. & 0.0412 & 0.0696 & - & - & - \\
O. stramineus & 0.0212 & 0.0174 & 0.0479 & - & - \\
O. fornesi & 0.0227 & 0.0247 & 0.0536 & 0.0143 & - \\
O. moojeni & 0.1120 & 0.1292 & 0.1334 & 0.1419 & 0.1354 \\
\hline
\end{tabular}


visualized in a UPGMA dendrogram (Figure 2). Two groups composed of 2 species each are clearly identified (O. stramineus $+O$. fornesi and O. flavescens + $O$. nigripes). Oligoryzomys sp. subsequently links to this group. $O$. moojeni is the most differentiated taxon, remaining outside the group that assembles the other 5 species. The same pattern was obtained when the Reynolds et al. (1983) distance was used (not shown).

\subsection{Population diversity and differentiation}

Eight populations of $O$. nigripes $(\mathrm{n}=123$ individuals) and 4 of $O$. flavescens $(\mathrm{n}=45)$ were investigated and an analysis of the diversity and differentiation patterns of the populations of these 2 Oligoryzomys species was made.

The results obtained in the analysis performed in 8 $O$. nigripes populations are shown in Table 4 . The number of phenotypes scored varied from 32 in Monte Verde to 51 in Mostardas and the average number of bands ranged from 10.9 in Corumbá to 17.8 in Sapiranga. The lowest and highest percentages of polymorphic bands were 38\% (Tainhas and Monte Verde) and 67\% (Mostardas), respectively, and the range for the average heterozygosity was 0.12 (Tainhas) -0.19 (Monte Verde). On the basis of pairwise $\phi_{\mathrm{ST}}$ estimates, there was significant genetic differentiation $\left(\phi_{\mathrm{ST}}=0.17 \pm 0.02 ; \mathrm{p}<0.001\right)$ for the $O$. nigripes populations investigated which is nonetheless unrelated with their geographical distances $\left(\mathrm{r}_{\mathrm{M}}\right.$ antel $=-0.38 ; \mathrm{p}=0.96$ ).

The same analysis was carried out in the $4 O$. flavescens populations (Table 5). Similar levels of intraspecies genetic diversity and differentiation were found for this species, as compared to $O$. nigripes populations. The percentage of polymorphic bands ranged from $36 \%$ in Taim to $59 \%$ in Charqueadas. The mean number of bands varied between 9.0 in Taim and 14.8 in Tainhas. The $O$. flavescens populations were significantly differentiated $\left(\phi_{\mathrm{ST}}=0.16 \pm 0.03\right.$; $\mathrm{P}<0.001$ ), but the genetic distances did not correlate with the geographical distances.

The RAPD affinities between the 8 populations of $O$. nigripes as measured by the Nei's standard genetic distances are depicted in the UPGMA dendrogram presented in Figure 3. Three clusters of 2 populations each can be visualized: Torres plus Monte Verde, Charqueadas plus Corumbá, and Osório plus Mostardas. These last four populations clustered together before the first two were added in a general group. The individuals of Sapiranga and Tainhas remained in a peripheral position and Tainhas were the more divergent population. The same pattern was observed in the dendrogram constructed with the Reynolds et al. (1983) genetic distance (not shown).

Table 4. RAPD genetic diversity in eight populations of Oligoryzomys nigripes: number of scored phenotypes, mean number of bands, percentage of polymorphic loci (99\% criterion) and unbiased average heterozygosity $\left(\mathrm{H}_{\mathrm{unb}}\right)$.

\begin{tabular}{lcccccccc}
\hline & \multicolumn{8}{c}{ Populations } \\
\cline { 2 - 9 } & CHA & TAH & SAP & OSO & MOS & TOR & MVE & COR \\
\hline $\mathrm{n}$ & 20 & 9 & 12 & 15 & 18 & 10 & 2 & 10 \\
Scored phenotypes & 48 & 31 & 48 & 49 & 51 & 41 & 32 & 43 \\
Mean number of bands & 12.8 & 13.8 & 17.8 & 13.9 & 13.8 & 15.1 & 17.5 & 10.9 \\
\pm SE (mean) & 0.69 & 0.95 & 0.92 & 0.77 & 0.72 & 1.00 & 1.50 & 0.82 \\
Polymorphic loci $(\%)$ & 63.2 & 38.2 & 60.5 & 64.4 & 67.1 & 52.6 & 38.2 & 56.6 \\
$\mathrm{H}_{\text {unb }}$ & 0.146 & 0.123 & 0.166 & 0.156 & 0.159 & 0.153 & 0.189 & 0.128 \\
\hline$\phi_{\text {ST }}=0.17 \pm 0.02 ; \mathrm{P}<0.001$ & & & & & & & \\
Mantel test: $\mathrm{r}=-0.38 ; \mathrm{P}=0.96$ & & & & & & & \\
\hline
\end{tabular}

Table 5. Genetic variability in RAPD markers studied in four populations of Oligoryzomys flavescens: number of scored phenotypes, mean number of bands, percentage of polymorphic loci (99\% criterion) and unbiased average heterozygosity $\left(\mathrm{H}_{\text {unb }}\right)$.

\begin{tabular}{lcccc}
\hline & \multicolumn{3}{c}{ Populations } \\
\cline { 2 - 5 } & CHA & TAH & TRA & TAI \\
\hline $\mathrm{n}$ & 11 & 10 & 7 & 6 \\
Scored phenotypes & 45 & 34 & 34 & 27 \\
Mean number of bands & 12.4 & 14.8 & 11.0 & 9.0 \\
土 SE (mean) & 0.96 & 1.22 & 1.34 & 35.5 \\
Polymorphic loci $(\%)$ & 59.2 & 42.1 & 44.7 & 0.104 \\
$\mathrm{H}_{\text {unb }}$ & 0.140 & 0.132 & 0.119 & \\
\hline$\phi_{\text {ST }}=0.16 \pm 0.03 ; \mathrm{p}<0.001$ & & & \\
Mantel test: $\mathrm{r}=-0.61 ; \mathrm{p}=0.785$ & & & \\
\hline
\end{tabular}



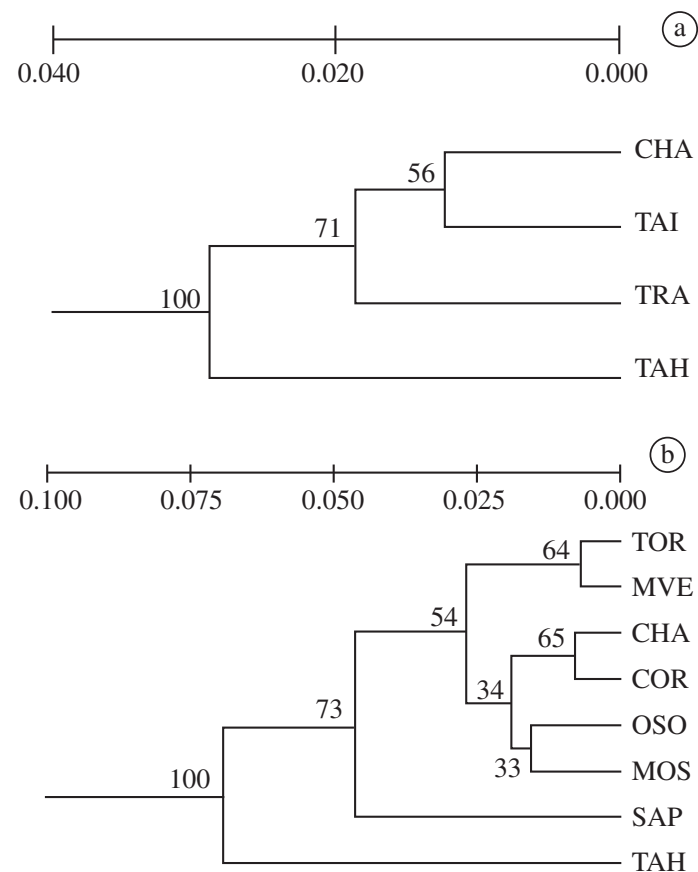

Figure 3. UPGMA dendrograms showing the genetic relationships among four populations of $O$. flavescens a) and eight populations of $O$. nigripes b), based on 75 RAPD markers. Numbers in the dendrogram represent bootstrap numbers obtained in 1,000 replications. CHA: Charqueadas; COR: Corumbá; MOS: Mostardas; MVE: Monte Verde; OSO: Osório; SAP: Sapiranga; TAH: Tainhas; TAI: Taim; TOR: Torres; TRA: Tramandaí.

Concerning the four populations of the species O. flavescens, the smallest genetic distance was found between the populations of Taim and Charqueadas to which Tramandaí and Tainhas progressively join (Figure 3).

\section{Discussion}

The few investigations performed on the genetic relationship between the Oligoryzomys's species based on molecules found them to be quite homogeneous. Dickerman and Yates (1995) and Perini et al. (2004), trying to solve the taxonomic position of Oligoryzomys and the relationships among its species by means of proteinelectrophoretic analysis, observed that the species of the genus are weakly differentiated, with no fixed differences among them as regards their allozymes patterns; and Chiappero et al. (1997) also using an enzyme-electrophoretic analysis to estimate the gene flow between populations of $O$. flavescens of Argentina detected a lack of isolation by distance pattern among these populations. Myers et al. (1995), studying the cytochrome b sequences in several species of Oligoryzomys, also found very little evidence of differentiation between their populations.

Of the 21 species listed by Musser and Carleton (2005) in the genus Oligoryzomys, 7 inhabit Brazil: $O$. chacoensis, O. delticola, O. eliurus, O. flavescens, $O$. fulvescens, $O$. microtis, and $O$. nigripes. Two of these species were investigated in the present study: $O$. nigripes (since $O$. delticola and $O$. nigripes were considered the same entity, see Andrades-Miranda et al., 2001, and others) and $O$. flavescens. We also analyzed two other species inhabiting the Cerrado biome, O. stramineus described by Bonvicino and Weksler (1998), and a taxon with the highest diploid number (70) of the genus that we found in a fauna inventory program performed previous to the construction of the UHE Serra da Mesa Power Project in the Upper Tocantins river (LimaRosa et al., 2000, and Andrades-Miranda et al., 2001), recently named $O$. moojeni by Weksler and Bonvicino (2005). Besides these two taxa from Cerrado we investigated Oligoryzomys sp., a taxon species collected in the Amazon biome (Roraima state).

On the contrary to the small interspecies diversity of genus Oligoryzomys reported in other genetic investigations, the RAPD analysis performed in this study depicted strong genetic differences among the taxa of this genus, and the genetic diversity estimates obtained were significantly different. The RAPD analysis performed in these taxa, on the contrary, was able to distinguish the 6 species and the 13 populations investigated showing that the Oligoryzomys's taxa are genetically well differentiated.

On the other hand, the cluster analyses made using the Nei's standard genetic distances did not show a clear base to the interspecies genetic relatedness of the Oligoryzomys species. It seems that the species did not group according to their geographical distribution areas (shared biomes, for instance), nor in agreement with the similarities of their karyotypes. Then it should be possible that the relationship they showed is the result of the particular biological history of each species, like the size of its populations in the past or the different ways or strategies they developed to explore and occupy its present-day territories.

The analysis of distances generated a dendrogram in which 2 groups, composed of 2 species each, are joined. In 1 of these groups $O$. flavescens and $O$. nigripes are coupled. These 2 species differ in morphology, $O$. nigripes having a large corporal size and $O$. flavescens which are included in the group of small sized Oligoryzomys species (Olds and Anderson, 1987; Carleton and Musser, 1989). They also differ in their chromosomal constitutions, $O$. nigripes presenting $2 \mathrm{n}=62$ with fundamental numbers (FN) varying from 78 to 82 owing to pericentric inversions, and $O$. flavescens showing diploid numbers of 64-67 due to accessory chromosomes (Sbalqueiro et al.,1991; Andrades-Miranda et al., 2001). Both species also differ regarding the geographical areas they live in. O. nigripes (Olfers 1818, an older name of delticola) occupies a wide-ranging area of South America, extending from northern Argentina to Paraguay, and from Uruguay and southern Brazil to the east, on the coast by parallel 15 (Bahia), and to the west until the Cerrado biome, in Central Brazil. O. flavescens was reported in Argentina, Uruguay, Bolivia, Paraguay and in several localities in 
southern Brazil. In 2 of these localities (Tainhas and Charqueadas) $O$. flavescens was trapped together with $O$. nigripes. The analysis made in respectively 8 and 4 populations of $O$. nigripes and $O$. flavescens revealed interspecies genetic diversity, but no clear geographical distance pattern for genetic similarities was observed.

Also in the dendogram generated from Nei's (1978) distances, the other pair of species linked to the pair $O$. nigripes - O. flavescens was $O$. fornesi and O. stramineus. Both these species differ in corporal size. O. stramineus is included in the group of the large size. Oligoryzomys and $O$. fornesi is one of the smallest taxon of the genus. O. stramineus $(2 \mathrm{n}=52, \mathrm{FN}=68$, AndradesMiranda et al., 2001) lives in the Cerrado area in northern Goiás and Minas Gerais states as well as in the Caatinga of the states of Paraíba and Pernambuco (Bonvicino and Weksler, 1998). O. fornesi $(2 \mathrm{n}=62, \mathrm{FN}=64 ; 66$ according to Andrades-Miranda et al., 2001), which has quite a confusing history of systematic location, is largely distributed, and is found in Paraguay and Argentina, as well as in Brazil, in the Cerrado (Goiás and Minas Gerais states) and Caatinga (Pernambuco) domains. The specimens of $O$.fornesi and $O$. stramineus of this study were trapped in the Cerrado biome but not in the same places (Corumbá and Serra da Mesa). O.fornesi was caught together with $O$. nigripes.

In Figure 2, it can also be seen that Oligoryzomys sp. is the taxon that subsequently links to the cluster $O$. nigripes - O. flavescens - O. fornesi - O. stramineus. This is an undescribed species trapped in Amapá which presented a $2 \mathrm{n}=66, \mathrm{FN}=74$ karyotype (AndradesMiranda et al., 2001). This species has not yet been described and presented $2 \mathrm{n}=66, \mathrm{FN}=74$ karyotype (Andrades-Miranda et al., 2001). Because of the similarity in chromosome constitution and because it was collected in the Amazonian, we first considered that it could be a taxon linked to $O$. microtis, whose type locality is in the lower Solimões River in the Brazilian Amazon, and is distributed throughout Central Brazil, south of Solimões-Amazon Rivers, and contiguous lowlands of Peru, Bolivia, Paraguay, and Argentina (Musser and Carleton, 2005). The data we obtained by sequencing a mitochondrial gene, however, clearly showed that although this species associates to other Amazonian Oligoryzomys taxa, it does not group with the specimens of $O$. microtis (Miranda et al., submitted). Hence, for its correct taxonomic identification a complete description of its morphology becomes necessary.

Joining externally to the other five Oligoryzomys's species analyzed, O. moojeni described by Weksler and Bonvicino (2005) appears. According to these authors, O. moojeni presents a high diploid number (70) as the most distinctive characteristic. O. moojeni inhabits the Cerrado biome (Goiás and Minas Gerais) and its type locality, Fazenda Fiandeira (at Chapada dos Veadeiros National Park, $14^{\circ} 05^{\prime} \mathrm{S}$ and $47^{\circ} 45^{\prime} \mathrm{W}$ ) is not very far away from the site where we collected the exemplars of this study $\left(13^{\circ} 45^{\prime} \mathrm{S}\right.$ and $\left.47^{\circ} 50^{\prime} \mathrm{W}\right)$.
In conclusion, the RAPD analyses performed in this work were successful in revealing significant genetic heterogeneity between the taxa and could help to discriminate the Oligoryzomys's populations and species, a genus up to now considered as being composed of species weakly genetic differentiated. However, the genetic relatedness between the Oligoryzomys's populations and species proved by this genetic marker, neither seems to be dependent on geographical distances nor to be a response to obvious biotic or abiotic processes shared by the taxa in the past.

Acknowledgments - Conselho Nacional de Desenvolvimento Científico e Tecnológico (CNPq), Financiadora de Estudos e Projetos (FINEP), Fundação de Amparo à Pesquisa do Estado do Rio Grande do Sul (FAPERGS), and the Organization of the American States (OAS) have supported this study. The authors are grateful to JLP. Cordeiro and AP. Nunes for field-work help and to LS. Silva for technical support.

\section{References}

ANDRADES-MIRANDA, J., OLIVEIRA, LFB., LIMAROSA, CAV., NUNES, AP, ZANCHIN, NIT. and MATTEVI, MS., 2001. Chromosomes studies in seven species of the genus Oligoryzomys (Rodentia: Sigmodontinae) from Brazil. Journal of Mammalogy, vol. 82, no. 4, p. 1080-1091.

BANGS, O., 1900. List of the mammals collected in the Santa Marta region of Colombia by W. W. Brown Jr. Proceedings of the New England Zoology Club, vol. 1, no. 1, p. 87-102.

BONVICINO, CR. and WEKSLER, M., 1998. A new species of Oligoryzomys (Rodentia, Sigmodontinae) from northeastern and central Brazil. Zeitschrift für Säugetierkunde, vol. 63, no. 1, p. $90-103$.

CARLETON, MD. and MUSSER, GG., 1989. Systematic studies of oryzomyine rodents (Muridae, Sigmodontinae): a synopsis of Microryzomys. Bulletin of the American Museum of Natural History, vol. 191, p. 1-83.

CHIAPPERO, MB, CALDERÓN, GE. and GARDENAL, CN.,1997.Oligoryzomys flavescens (Rodentia, Muridae): gene flow among populations from central-eastern Argentina. Genetica, vol. 101, no. 2, p. 105-113.

D’ELÍA, G., 2003. Phylogenetics of Sigmodontinae (Rodentia, Muroidea, Cricetidae), with special reference to the akodont group and with additional comments on historical biogeography. Cladistics, vol. 19, no. 4, p. 307-323.

DICKERMAN, AW. and YATES, TL., 1995. Systematics of Oligoryzomys: Protein-electrophoretic analyses. Journal of Mammalogy, vol. 76, no. 1, p. 172-188.

EMMONS, LH. and FEER, F., 1990. Neotropical rainforest mammals: a field guide. The University of Chicago Press, Chicago, Illinois.

ENGEL, SR, HOGAN, KM, TAYLOR, JF. and DAVIS, SK., 1998. Molecular systematics and paleobiogeography of the South American Sigmodontinae rodents. Molecular Biology and Evolution, vol. 15, no. 1, p. 35-49.

EXCOFFIER, L., SMOUSE, PE. and QUATTRO, JM., 1992. Analysis of molecular variance inferred from metric distances among DNA haplotypes: application to human mitochondrial DNA restriction data. Genetics, vol. 131, no. 4, p. 479-491. 
GARDNER, AL. and PATTON, JL., 1976. Karyotypic variation in chromosomal evolution in the neotropical cricetine complex. Occasional Papers, Museum of Zoology, Louisiana State University, vol. 49, no. 1, p. 1-48.

HERSHKOVITZ, P., 1966. South American swamp and fossorial rats of the scapteromyine group (Cricetinae, Muridae) with comments on the glans penis in murid taxonomy. Sonderdruck aus Zeistschrift für Saügetierkunde, vol. 31, no. 2, p. 81-149.

HERSHKOVITZ, P., 1972. The recent mammals of the Neotropical Region: a zoogeographic and ecological review. In KEAST, A., ERK, FC. and GLASS, B. (Editors). Evolutions, mammals, and southern continents. State University of New York Press, Albany.

HOOPER, ET. and MUSSER, GG., 1964. The glans penis in neotropical cricetines (family Muridae) with comments on classification of muroid rodents. Misc. Pub. Mus. Zool., University of Michigan, vol. 123, p. 1.

LIMA-ROSA, CAV., HUTZ, MH., OLIVEIRA, LFB., ANDRADES-MIRANDA, J. and MATTEVI, MS., 2000. Heterologous amplification of microsatellite loci from mice and rat in oryzomyini and thomasomyini South American rodents. Biochemical Genetics, vol. 38, no. 1, p. 97-108.

LYNCH, M. and MILLINGAN, BG., 1994. Analysis of population structure with RAPD markers. Molecular Ecology, vol. 3, no. 1, p. 91-99.

MANTEL, N., 1967. The detection of disease clustering and a generalized regression approach. Cancer Research, vol. 24, no. 3 , p. $209-220$

MEDRANO, JF., AASEN, E. and SHARROW, L., 1990. DNA extraction nucleated red blood cells. Biotechniques, vol. 8, no. 1, p. 43.

MILLER, MP. 1997, Tools for population genetic analyses (TFPGA) 1.3: A Windows program for the analysis of allozyme and molecular population genetic data. Computed software distributed by the author (Department of Forest, Range and Wildlife, Utah State University, 5230 Old Main Hill, Logan Utah 84322-5230, USA; http://bioweb.usu.edu/mpmbio/).

MUSSER GG. and CARLETON MD., 2005. Super Family Muroidea. In WILSON DE., REEDER DM., editors. Mammal species of the world: a taxonomic and geographic reference. Baltimore: Johns Hopkins University Press. p. 894-1531.

MYERS, P., LUNDRIGAN, B. and TUCKER, PK., 1995. Molecular phylogenetics of oryzomyine rodents: the genus Oligoryzomys. Molecular Phylogenetics and Evolution, vol. 4, no. 4 , p. $372-382$

NEI, M., 1978. Estimation of average heterozygosity and genetic distance from a small number of individuals. Genetics, vol. 89 , no. 3 , p. $583-590$.

NEI, M. and ROYCHOUDHURY, AK., 1974. Sampling variance heterozygosity and genetic distance. Genetics, vol. 76, no. 2, p. 379-390.

OLDS, N. and ANDERSON, S., 1987. Notes on Bolivian Mammals 2. Taxonomy and distribution of rice rats of the genus Oligoryzomys. In: Studies in Neotropical mammalogy: essays in honor of Philip Hershkovitz. Ed. by B. D. Patterson and R. M. Timm. Fieldiana Zoology New, vol. 39, p. 261-281.

PATTON, JL., SILVA, MNF. and MALCOLM, JR., 1996. Hierarchical genetic structure and gene flow in three sympatric species of Amazonian rodents. Molecular Ecology, vol. 5, no. 2, p. 229-238.
PERINI, MV., WEIMER, TA., CALLEGARI-JACQUES, S. M. and MATTEVI, MS., 2004. Biochemical polymorphisms and genetic relationships in rodents of the genera Oryzomys and Oligoryzomys (Sigmodontinae) from Brazil. Biochemical Genetics, vol. 42, no. 9-10, p. 317-329.

POWERS, AM., MERCER, DR., WATTS, DM., GUZMAN, H., FULHORST, CF., POPOV, VL. and TESH, RB., 1999. Isolation and genetic characterization of a hantavirus (Bunyaviridae: Hantavirus) from a rodent, Oligoryzomys microtis (Muridae), collected in northeastern Peru. American Journal of Tropical Medicine and Hygiene, vol. 61, no. 1, p. 92-98.

REIG, OA., 1980. A new fossil genus of South American cricetid rodents allied to Wiedomys, with an assessment of the Sigmodontinae. J. Zool., vol. 192, p. 257.

REIG, OA., 1981. Teoria del origen y desarrollo de la fauna de mamíferos de América del Sur. Monograf. Naturae Mus. Munic. Cienc. Nat. Lorenzo Scaglia, vol. 1, p. 1-161.

REIG, OA., 1984. Distribuição geográfica e história evolutiva dos roedores muroides sul-americanos (Cricetidae, Sigmodontinae). Revista Brasileira de Genética, vol. 7, no. 3, p. 333-365.

REIG, OA., 1986. Diversity Patterns and Differentiation of High Andean Rodents. (In: High Altitude Tropical Biogeography: 404-440. F. Vuilleumier and M. Monasteiro, edts.) Oxford Univ. Press, New York. 649p.

REYNOLDS, J., WEIR, BS. and COCKERHAM, CC.,1983. Estimation of the coancestry coefficient: basis for a short-term genetic distance. Genetics, vol. 105, no. 3, p. 767-779.

SBALQUEIRO IJ., MATTEVI MS., OLIVEIRA LF. and SOLANO MJV., 1991. B chromosome system in populations of Oryzomys flavescens (Rodentia, Cricetidae) from southern Brazil. Act. Ther., vol. 36, no. 1, p. 193-199.

SCHNEIDER, S., ROESSLI, D. and EXCOFFIER, L., 2001. Arlequin (ver. 2001) - a software for population genetics data analysis. Geneva: University of Geneva.

SMITH, MF. and PATTON, JL., 1999. Phylogenetic relationships and the radiation of Sigmodontinae rodents in South America: evidence from cytochrome b. Journal of Mammalian Evolution, vol. 6 , no. 1 , p. 89-128.

SMOUSE, PE. and LONG, JC., 1992. Matrix correlation analysis in Anthropology and Genetics. Year Book of Physical Anthropology, vol. 35, no. 1, p. 187-213.

VOSS, RS. and LINZEY, AV., 1981. Comparative gross morphology of male accessory glands among Neotropical Muridae (Mammalia, Rodentia) with comments on systematic implications. Museum Zoology University Michigan, vol. 159, no. 1 , p. $1-41$.

WEIR, BS., 1996. Genetic data analysis II: methods for discrete population genetic data. Sunderland, MA: Sinauer.

WEIR, BS. and COCKERHAM, CC., 1984. Estimating Fstatistics for the analysis of population structure. Evolution, vol. 38 , no. 66 , p. $1358-1370$.

WEKSLER, M., 2003. Phylogeny of Neotropical oryzomyine rodents (Muridae: Sigmodontinae) based on the nuclear IRBP exon. Mol. Phylogenet. Evol., vol. 29, no. 2, p. 331-49.

WEKSLER, M. and BONVICINO, CR., 2005. Taxonomy of pigmy rice rats (genus Oligoryzomys, Rodentia, Sigmodontinae) of the Brazilian Cerrado. Arq. Mus. Nac., vol. 63, no. 1, p. $113-130$.

WILLIAMS, JGK, KUBELIK, AR, LIVAK, J, RAFALSKI, JA. and TINGEY, SV., 1990. DNA polymorphisms amplified by arbitrary primers are useful as genetic markers. Nucleic Acids Research, vol. 18, no. 22, p. 6531-6535. 